\title{
Experimental Study on Preparation and Properties of Zir- conium Boride Reinforced NbMo-matrix Composites
}

\author{
Wang Qi, Liu Zongde, Hu Huidong, Gao Yuan, Wang Yongtian \\ Key Laboratory of Condition Monitoring and Control for Power Plant Equipment of Ministry of Education, North China Electric Power University, \\ Beijing 102206, China
}

\begin{abstract}
Zirconium boride reinforced NbMo-matrix composites with composition of $42.5 \% \mathrm{Nb}+42.5 \% \mathrm{Mo}+15 \% \mathrm{ZrB}_{2}(\mathrm{vol} \%)$ and $42.5 \% \mathrm{Nb}+42.5 \% \mathrm{Mo}+10.5 \% \mathrm{ZrB}_{2}+4.5 \% \mathrm{SiC}(\mathrm{vol} \%)$ were fabricated by hot-pressing under an uniaxial load of $30 \mathrm{MPa}$ at $1600{ }^{\circ} \mathrm{C}$ in Ar atmosphere with holding time of $1 \mathrm{~h}$ and $2 \mathrm{~h}$. The microstructure and phase composition were analyzed by SEM, EDS and XRD. The mechanical properties were measured by Micro Vickers and hydraulic universal tester. Results show that small ZrB particles are distributed uniformly in NbMo solid solution. Residual $\mathrm{SiC}$ and formed $\mathrm{MoSi}_{2}$ are found in the samples with $\mathrm{SiC}$. The compressive strength is improved to 1974.17 MPa from 1380.15 MPa of the NbMo solid solution. The yield stress is improved to 1664.13 MPa and the hardness is 3 5 times higher than that of NbMo. The longer holding time ( $2 \mathrm{~h})$ leads to the higher strength, yield stress and hardness. The increase in strength and hardness of the composites is a consequence of the solid solution strengthening mechanism and the excellent interface bonding between $\mathrm{ZrB}$ and Nb-Mo solid solution.
\end{abstract}

Key words: zirconium boride; hot-pressing; microstructure; mechanical property

The properties of high strength and fracture toughness at high temperatures as well as excellent thermal shock resistance make the refractory alloys play a very important role in high temperature industries, such as aviation and rocket engine, space nuclear power systems and gas turbines. Particularly, niobium $(\mathrm{Nb})$ and molybdenum (Mo) alloys are more widely used than other refractory alloys. $\mathrm{Nb}$ and $\mathrm{Nb}$-based alloys have a widespread use in the aerospace industry for their high melting points and strength at high temperatures and good corrosion resistance ${ }^{[1,2]}$. Major drawback of $\mathrm{Nb}$ and $\mathrm{Mo}$ alloy are their low oxidation resistance and poor strength at high temperature above $1200^{\circ} \mathrm{C}$ which seriously restricts their practical application at high temperature field. As a result, one effective way to improve the high temperature oxidation resistance and high temperature strength of NbMo alloy is strictly needed ${ }^{[3]}$. To address this issue, zirconium boride, titanium carbide particles were used as ceramic strengthening phase in $\mathrm{Nb}$ and NbMo-alloys.

$\mathrm{ZrB}_{2}$-matrix materials have been used broadly in the air-crafts, high-temperature electrodes etc ${ }^{[4]}$ because of high strength and melting point, chemical stability, unique resistance to thermal shocks, good electrical and thermal conductivity ${ }^{[5]}$. However, it is difficult to prepare dense $\mathrm{ZrB}_{2}$ materials at low-temperatures for their high melting point and strong covalent bonding. Densification of $\mathrm{ZrB}_{2}$ without any additive needs to be hot-pressing sintered at $2100 \sim 2300{ }^{\circ} \mathrm{C}^{[6]}$. Moreover, the weakness of $\mathrm{ZrB}_{2}$ is its brittleness and low toughness. Previous studies suggested that by adding ceramic particles as the second phase to other high toughness materials or adding metal elements in the ceramics matrix, the excellent performance is achieved. $\mathrm{SiC}$ is known for high temperature oxidation resistance above $1200{ }^{\circ} \mathrm{C}$ because of the formation of silicate glass as a protective layer. Many researchers studied $\mathrm{ZrB}_{2}-\mathrm{SiC}$ composites and found that oxidation resistance of the composites could be improved by adding $\mathrm{SiC}$ into $\mathrm{ZrB}_{2}$ [7-9].

In order to improve the toughness of $\mathrm{ZrB}_{2}$ based ceramics, Sun et al ${ }^{[10]}$ studied the microstructure and mechanical proper-

Received date: September 25,2016

Foundation item: National Natural Science Foundation of China (11372110)

Corresponding author: Liu Zongde, Ph. D., Professor, Key Laboratory of Condition Monitoring and Control for Power Plant Equipment of Ministry of Education, North China Electric Power University, Beijing 102206, P. R. China, Tel: 0086-10-61772812, E-mail: 1zd@ncepu.edu.cn 
ties of $\mathrm{Nb}-\mathrm{ZrB}_{2}$ composite by hot-pressing sintering process. The results showed that the fracture toughness and strength were improved markedly with $\mathrm{Nb}$ addition. Y. Tan et $\mathrm{al}^{[11,12]}$ prepared $\mathrm{NbMo}-\mathrm{ZrC}$ composites by arc melting, and the results showed that the compressive strength of NbMo- $\mathrm{ZrC}$ alloy was significantly improved due to the addition of Mo. However the ceramics particles $\mathrm{ZrB}_{2}$ reinforced $\mathrm{NbMo}$ solid solution matrix composites haven't been fabricated by now and the mechanical properties haven't been measured yet ${ }^{[13-15]}$.

Overall, the study of ceramic particle reinforced ultra-high temperature refractory metal composites is still in experimental stage, and the high temperature mechanical data is still very limited. In the present work, we fabricated NbMo-based composite reinforced by zirconium boride particles using hot-pressing successfully. The dopant of SiC was used to improve oxidation resistance. The objective of this paper is to explore the feasibility of preparation of zirconium boride reinforced NbMo-matrix composites and analyze the effect of holding time and additive $\mathrm{SiC}$ on the mechanical properties. The improvement of strength and oxidation resistance in high temperature and ultra-high temperature will be achieved through different process parameters.

\section{Experiment}

Five powder mixtures were prepared (vol\%) and two kinds of holding time (h) were set:

\section{A0: $50 \% \mathrm{Nb}+50 \% \mathrm{Mo}+2 \mathrm{~h}$}

A1: $42.5 \% \mathrm{Nb}+42.5 \% \mathrm{Mo}+15 \% \mathrm{ZrB}_{2}+1 \mathrm{~h}$
A2: $42.5 \% \mathrm{Nb}+42.5 \% \mathrm{Mo}+15 \% \mathrm{ZrB}_{2}+2 \mathrm{~h}$
B1: $42.5 \% \mathrm{Nb}+42.5 \% \mathrm{Mo}+10.5 \% \mathrm{ZrB}_{2}+4.5 \% \mathrm{SiC}+1 \mathrm{~h}$
B2: $42.5 \% \mathrm{Nb}+42.5 \% \mathrm{Mo}+10.5 \% \mathrm{ZrB}_{2}+4.5 \% \mathrm{SiC}+2 \mathrm{~h}$

Different holding time was set to investigated the process parameters during hot-pressing, A0 was set as contrast, and material A (A1, A2) and material B (B1, B2) were used for the study of the difference between different compositions.

Commercially available $\mathrm{ZrB}_{2}(19 \sim 30 \mu \mathrm{m}$, purity $>99.95 \%)$ and $\mathrm{SiC}(\leqslant 43 \mu \mathrm{m}$, purity $>99.9 \%)$, Nb Mo $(19 \sim 30 \mu \mathrm{m}$, purity $>99.95 \%$ ) powders were used as raw materials in this study. They were supplied from Northwest Institute for Non-ferrous Metal Research and Zhu Zhou Cemented Carbide Group Co. Ltd. China. All the powders were homogeneously mixed according to the ratios using a planetary ball mill with stainless steel milling containers and steel balls. The rotation speed was set at $200 \mathrm{r} \cdot \mathrm{min}^{-1}$ and the milling time was $4 \mathrm{~h}$. After rotation, the powder mixtures were dried at $120^{\circ} \mathrm{C}$ for $4 \mathrm{~h}$ followed by being hot-pressed at $1600{ }^{\circ} \mathrm{C}$ using vacuum induction hot pressing furnace ZT-30-22Y. After hot-pressing, we acquired some bulks with the size of $36 \mathrm{~mm} \times 25 \mathrm{~mm} \times 10 \mathrm{~mm}$. All the samples were sectioned into $10 \mathrm{~mm} \times 10 \mathrm{~mm} \times 4 \mathrm{~mm}$ pieces by wire cut electrical discharge machining (WEDM), and then ultrasonically cleaned with alcohol. For phase identification and microstructure characterization, the surfaces and cross-sections of the samples were wet ground through successive $\mathrm{SiC}$ papers from $280^{\#}$ to $1200^{\#}$, followed by being polished. X-ray diffraction patterns were acquired by RIGAKU DMAX-2500 using $\mathrm{Cu}$ $\mathrm{K} \alpha$ radiation, between $2 \theta$ angles of $10^{\circ}$ and $90^{\circ}$. Microstructures were observed by scanning electron microscopy using ZEISS SUPRA 55 in back-scattered electron mode. Elementary composition was examined by Energy Dispersive Spectrometer. The Vickers hardness was acquired using Micro Vickers tester FM-300 with a load of $1000 \mathrm{~g}$ and a dwell time of $20 \mathrm{~s}$. Compression test was conducted in air at room temperature by a hydraulic universal tester. The yield stress was calculated using the data from compression test.

\section{Results and Discussion}

\subsection{Microstructure}

XRD patterns of the five materials are shown in Fig.1. From the diffraction peaks, we can conclude that the main phases of all the ceramic particles reinforced composites are NbMo solid solution and $\mathrm{ZrB}$ particles, and the peaks of $\mathrm{SiC}$ and $\mathrm{MoSi}_{2}$ are found only in $\mathrm{B} 1$ and B2. The NbMo solid solution is formed easily during hot-pressing because $\mathrm{Nb}$ and Mo have the same body-centered cubic lattice with the close lattice parameters $0.3300 \mathrm{~nm}, 0.3147 \mathrm{~nm}$, respectively. However, they don't form homogeneous solid solution. Two kinds of solid solution can be observed by SEM as shown in Fig.2. The peak of $\mathrm{ZrB}$ indicates that $\mathrm{ZrB}_{2}$ resolves during hot-pressing. B may diffuse into NbMo solid solution, but we cannot find its peak or element distribution since the amount of BNbMo solid solution is small and the accurate amount of B cannot be acquired through EDS. SiC resolve partly, and $\mathrm{MoSi}_{2}$ are formed from resolved $\mathrm{SiC}$ and Mo according to the results investigated by $\mathrm{Li}$ et al ${ }^{[16]}$.

There are three phases in Fig.2b and Fig.2c, the grey phase, the light grey phase and the small black particles. EDS analysis reveals that the small black particles are $\mathrm{ZrB}$ particles distributed uniformly in the NbMo solid solution matrix. Grey and light grey phases are all NbMo solid solutions, but in the grey phase, the content of $\mathrm{Nb}$ is more than the light grey phase.

The elementary compositions of EDS scan are also displayed in Fig.2. It can be seen that the A1 and A2 are free of cracks and pores; however there are a lot of pores in A0, B1 and B2. The

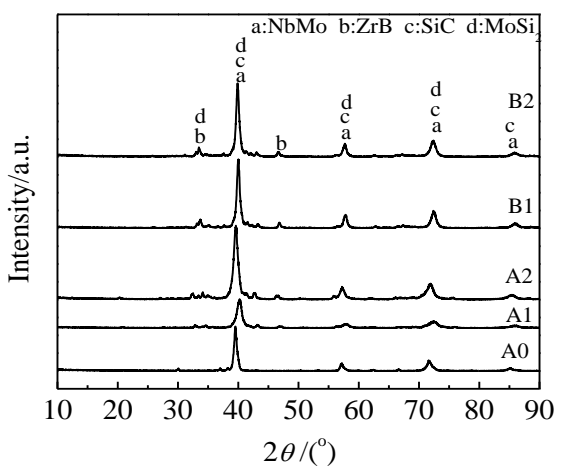


Fig.1 XRD patterns of five materials

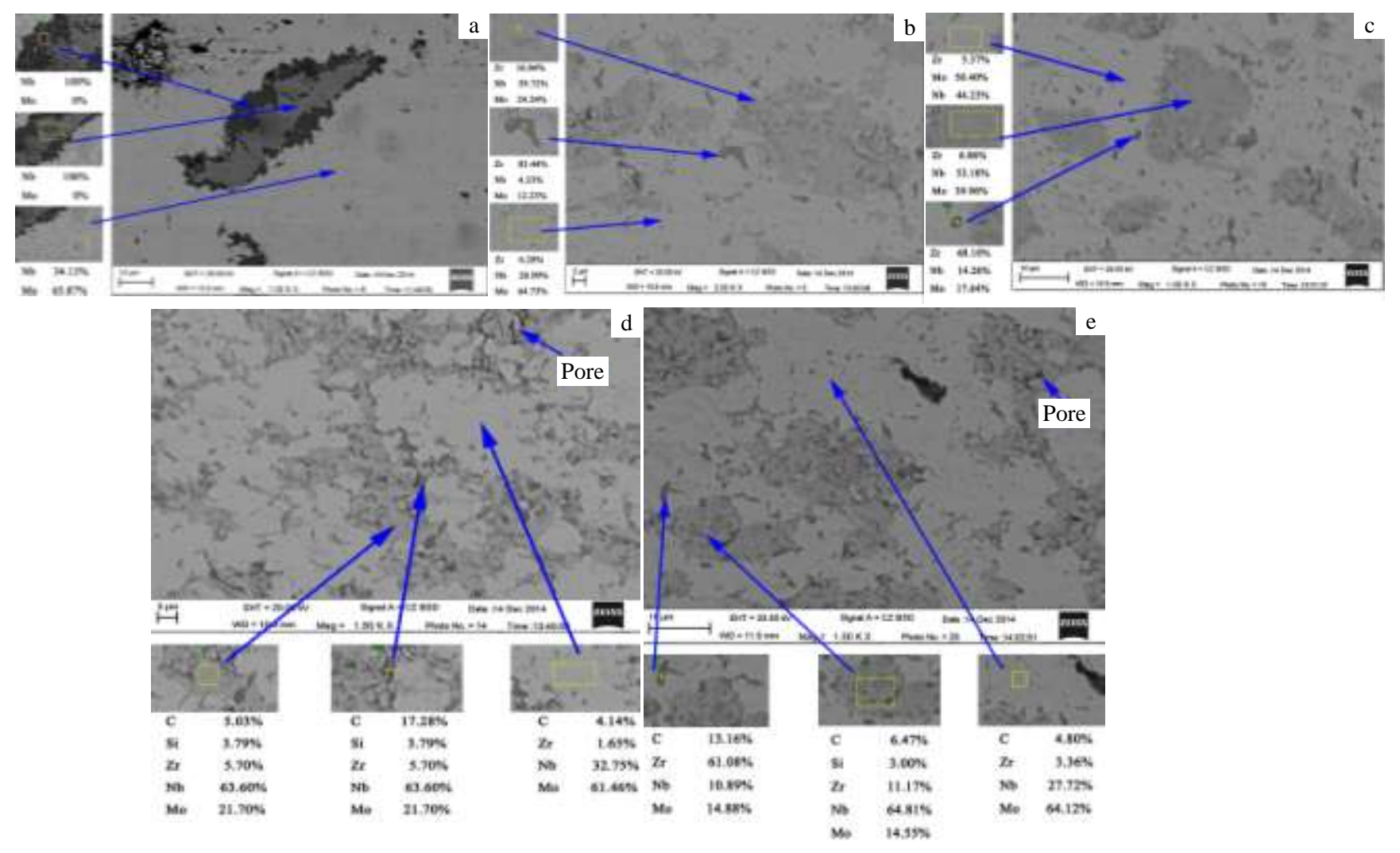

Fig.2 Elementary composition (wt\%) by EDS analysis for A0 (a), A1 (b), A2 (c), B1 (d), and B2 (e)

reason for the existence of pores in $\mathrm{B} 1$ and $\mathrm{B} 2$ is that the $\mathrm{SiC}$ suppresses the interdiffusion between $\mathrm{MoSi}_{2}$ and $\mathrm{Nb}$, and there are also pores in the interface between the $\mathrm{MoSi}_{2}$ and $\mathrm{SiC}$ in Kurokawa K's experiment ${ }^{[17]}$. The elementary composites in Fig.2d and Fig.2e convince the existence of $\mathrm{MoSi}_{2}$ and $\mathrm{SiC}$.

Comparing the elementary compositions in Fig. $2 \mathrm{~b}$ with Fig.2c, the solid solutions phases distribute more uniformly during long holding time $2 \mathrm{~h}$ which may contribute to the high strength and hardness. The pores in the A0, B1, B2 signed in Fig.2a Fig.2d and Fig.2e may lead to poor mechanical properties.

\subsection{Mechanical properties}

Fig. 3 shows typical examples of compressive stress-strain curves of the four different alloys compared with single NbMo solid solution deformed at room temperature. Specimens display a definite stress drop for all the four alloys after deviating from linear elastic behavior. That indicates that $\mathrm{A}$ and $\mathrm{B}$ are all brittle materials. Comprehensive strength improves significantly compared to the single NbMo solid solution.

The compression strength and yield stress of the five samples are summarized in Table 1. The longer the holding time ( $2 \mathrm{~h}$ ), the higher the strength, yield stress and hardness. The $\sigma_{0.2}, \sigma_{\mathrm{bc}}$ and hardness of $\mathrm{A} 1$ are $1263.37 \mathrm{MPa}, 1357.58 \mathrm{MPa}$, $5700 \mathrm{MPa}(\mathrm{HV})$ and those of A2 are 1664.13 MPa, 1974.17 $\mathrm{MPa}, 6870 \mathrm{MPa}(\mathrm{HV})$, respectively. B1 and B2 have the same tendency. This phenomenon is in good agreement with the change in the microstructure. It appears that the maximum solid solution effects can be achieved when the $\mathrm{Nb} / \mathrm{Mo}$ ratio is around 1. High mechanical properties are the consequence of the component uniformity of NbMo-matrix as discussed above.

The dopant of $\mathrm{SiC}$ decreases the reinforced influence of $\mathrm{ZrB}_{2}$ particles as shown in Fig.3. This phenomenon is due to the pores in B1, B2 signed in Fig.2d, Fig.2e, respectively. As a result, the improved bonding of interface between ceramic particles and NbMo-matrix enhances the strength, hardness and yield stress when comparing material A with porous material B.

Table 1 Mechanical properties of five materials

\begin{tabular}{cccc}
\hline \multirow{2}{*}{ Material } & $\begin{array}{c}\text { Yield stress } \\
\sigma_{0.2} / \mathrm{MPa}\end{array}$ & $\begin{array}{c}\text { Compress strength } \\
\sigma_{\mathrm{bc}} / \mathrm{MPa}\end{array}$ & $\begin{array}{c}\mathrm{HV} / \times 10 \\
\mathrm{MPa}\end{array}$ \\
\hline A0 & 1038.74 & 1380.15 & 184.1 \\
$\mathrm{~A} 1$ & 1263.37 & 1357.58 & 570 \\
$\mathrm{~A} 2$ & 1664.13 & 1974.17 & 687
\end{tabular}




\begin{tabular}{llll} 
B1 & 1145.02 & 1344.93 & 780 \\
B2 & 1331.59 & 1437.35 & 848 \\
\hline
\end{tabular}

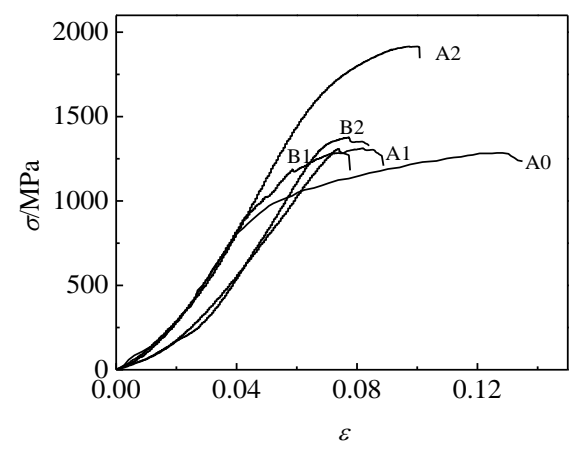

Fig.3 Compressive stress-strain curves of the four different alloys

\section{Conclusions}

1) Zirconium boride reinforced NbMo-matrix composites with or without $\mathrm{SiC}$ doping show the better mechanical properties than NbMo-matrix. Two kinds of solid solution of $\mathrm{NbMo}$ is observed, one is rich in $\mathrm{Nb}$ and the other is rich in Mo. Small $\mathrm{ZrB}$ particles are distributed uniformly in the NbMo solid solution matrix. Residual SiC and formed $\mathrm{MoSi}_{2}$ are found in composites with $\mathrm{SiC}$ doped.

2) $\mathrm{ZrB}_{2}$ particles reinforce the NbMo-matrix, and the dopant of $\mathrm{ZrB}_{2}$ ceramic particles lead to high yield stress and hardness. The existence of $\mathrm{SiC}$ and $\mathrm{MoSi}_{2}$ in composites with $\mathrm{SiC}$ doped result in pores.

3) With long holding time of $2 \mathrm{~h}$ during hot-pressing progress, the microstructure of the composites becomes more uniform and the yield stress, compressive strength, and hardness are improved significantly. The increment could be attributed to the excellent interface bonding between $\mathrm{ZrB}$ and $\mathrm{NbMo}$ and the solid solution strengthening mechanism resulting from long holding time.

\section{References}

1 Nico C, Monteiro T, Grace MPF. Progress in Materials Science $[\mathrm{J}], 2016,80: 1$

2 Zhong N, Wang X D, Wang L et al. Mater Sci Ed A[J], 2009, 506: 111

3 Yonosuke Murayama, Shuji Hanada. Science and Technology of Advanced Materials [J], 2002, 3(2): 145

4 Monteverde F, Bellosi A, Guicciardi S. J Eur Ceram Soc [J], 2002, 22: 279

5 Zhu S, Fahrenholtz W G, Hilmas G E et al. Composites[J], 2008, 39(A): 449

6 Zhu S, Fahrenholtz W G, Hilmas G E. Scripta Mater[J], 2008, 59: 123

7 Monteverde F, Guicciardi S, Bellosi A. Mater Sci Ed A [J], 2003, A346: 310

8 Wang Hailong, Chen Deliang, Wang Chang-An. Int $J$ of Refractory Metals \& Hard Materials [J], 2009, 27: 1024

9 Bartolomeâ J F, Dõâaz M, Requena J et al. Acta Mater [J], 1999, 47: 3891

10 Sun Xin, Han Wenbo, Hu Ping. Int J of Refractory Metals \& Hard Materials [J], 2010, 48: 472

11 Tan Y, Ma C L, Kasama A. Materials Science and Engineering A [J], 2003, 355: 260

12 Alman D E, Hawk J A. Wear[J], 2001, 251: 890

13 Zhu T, Xu L, Zhang X H et al. J Eur Ceram Soc[J], 2009, 29: 2893

14 Liu Weiwei, Zhang Lu, Yue Chunguang et al. Rare Metal Materials and Engineering $[\mathrm{J}], 2014,43: 2567$

15 Wei Hongmei, Yang Weiqi, Lin Tiesong et al. Rare Metal Materials and Engineering[J], 2013, 42: 662

16 Li Changqing, Zhang Juncai, Wu Wanliang et al. Journal of Heilongjiang Institute of Science \& Technology[J], 2009, 19(3): 206

17 Kurokawa K, Ochiai G, Takahashi Hi et al. Vacuum[J], 2000, 59(1): 284

\title{
$\mathrm{ZrB}_{2}$ 增强 NbMo 基复合材料制备及性能研究
}

王 琦, 刘宗德, 胡慧东, 高 远, 王永田

(华北电力大学 电站设备状态检测与控制教育部重点实验室, 北京 102206)

\begin{abstract}
摘 要：采用真空热压烧结法制备两种成分的 $\mathrm{ZrB}_{2}$ 增强 $\mathrm{NbMo}$ 基复合材料： $42.5 \% \mathrm{Nb}+42.5 \% \mathrm{Mo}+15 \% \mathrm{ZrB} 2 、 42.5 \% \mathrm{Nb}+42.5 \% \mathrm{Mo}+$ $10.5 \% \mathrm{ZrB}_{2}+4.5 \% \mathrm{SiC}$ (体积分数)。烧结工艺为温度 $1600{ }^{\circ} \mathrm{C}$, 轴向应力 $30 \mathrm{MPa}$, 保护气体为氩气，保温时间分为 $1 \mathrm{~h}$ 和 $2 \mathrm{~h}$ 。使用扫描 电子显微镜、能谱分析仪和 $\mathrm{X}$ 射线衍射仪分析材料的微观结构和相组成, 使用显微维氏硬度计和液压式万能试验机检测材料的力学性 能。研究发现, $\mathrm{ZrB}$ 颗粒均匀分布于 $\mathrm{NbMo}$ 固溶体中, 在添加 $\mathrm{SiC}$ 的样品中有 $\mathrm{SiC}$ 的剩余以及 $\mathrm{MoSi}_{2}$ 相的生成。与无陶瓷相添加的样品 相比, 添加陶瓷相的样品的抗压强度由 1380.15 MPa 提高至 1974.17 MPa, 屈服强度提高至 1664.13 MPa, 硬度提高 3 5 倍。保温时间 越长, 材料的抗压强度、屈服强度和硬度越高。复合材料强度和硬度提高是固溶强化以及 $\mathrm{ZrB}$ 和 $\mathrm{NbMo}$ 之间良好的界面结合力的结果。
\end{abstract} 关键词: $\mathrm{ZrB}_{2}$; 热压烧结; 微观结构; 力学性能 
作者简介: 王 琦, 女, 1992 年生, 博士生, 华北电力大学热能工程专业, 北京 102206, E-mail: beautylover@yeah.net 